Article

\title{
Impacts of Low-Carbon Innovation and Its Heterogeneous Components on $\mathrm{CO}_{2}$ Emissions
}

\author{
Zheming Yan ${ }^{1,2}$, Lan Yi ${ }^{1}$, Kerui Du ${ }^{3, *}$ and Zhiming Yang ${ }^{4}$ \\ 1 International Business School, Shaanxi Normal University, Xi'an 710119, China; \\ zhemingyan@snnu.edu.cn (Z.Y.); yilan@snnu.edu.cn (L.Y.) \\ 2 School of Finance and Economics, Xi'an Jiaotong University, Xi'an 710061, China \\ 3 Center for Economic Research, Shandong University, Jinan 250100, China \\ 4 Donlinks School of Economics and Management, University of Science and Technology Beijing, \\ Beijing 100083, China; zhiming0419@126.com \\ * Correspondence: kerrydu@sdu.edu.cn
}

Academic Editors: Ning Zhang, Liexun Yang and Peng Zhou

Received: 3 February 2017; Accepted: 1 April 2017; Published: 5 April 2017

\begin{abstract}
This paper aims to investigate the impact of low-carbon innovation on $\mathrm{CO}_{2}$ emissions. Using patent statistics, we measured low-carbon innovations for 15 major economies during the period of 1992-2012. Then, we classified low-carbon technology into clean and gray technology according to the patent classification system. Following the empirical Environmental Kuznets Curve (EKC) framework, we explored the effects of low-carbon innovation and its components on $\mathrm{CO}_{2}$ emissions. We did not find any evidence of significant influence of low-carbon innovation. Through further estimations, a significantly negative effect of clean innovation was found while the effect of gray innovation is not clear. Heterogeneous impacts within low-carbon technology provide an explanation for the insignificant impact of low-carbon innovation.
\end{abstract}

Keywords: low carbon technologies; clean innovation; gray innovation; patent statistics; $\mathrm{CO}_{2}$ emissions

\section{Introduction}

Technology may help solve our climate change issues. Low-carbon technology innovation, or a broader concept of technology innovation for climate change mitigation, attracts increasing attention from both entrepreneurs and policymakers [1]. During COP21, a dozen of the most brilliant entrepreneurs in the world established an investment fund, the Breakthrough Energy Coalition (BEC), aimed at accelerating the cycle of low-carbon energy innovation. As noted by BEC, "the existing system of basic research, clean energy investment, regulatory frameworks, and subsidies fails to sufficiently mobilize investment for truly transformative energy solutions for the future". So from the perspective of global leaders, the existing low-carbon technology system is unsatisfactory in terms of its capability of climate change mitigation. However, in the context of ecological or energy economics, existing studies typically took it for granted that environmental innovations (EI) had a significantly negative effect on $\mathrm{CO}_{2}$ emissions [2]. Hence it is interesting to consider whether widely-used low-carbon technology is playing an expected role in the global mission of $\mathrm{CO}_{2}$ reduction. Specifically, there are several issues to be investigated. Firstly, is low-carbon innovation necessarily related to $\mathrm{CO}_{2}$ reduction? Secondly, low-carbon technology consists of many subclasses including energy efficiency technology and electric vehicle technology etc., but how effective is each subclass of low-carbon technology in achieving $\mathrm{CO}_{2}$ reduction goals? Investigating the effects of low-carbon innovation and its components on $\mathrm{CO}_{2}$ emission is helpful for policy-making regarding our low-carbon future.

This paper aims to investigate the impact of low-carbon innovation on $\mathrm{CO}_{2}$ emission, from the perspective of heterogeneous classifications in the technological domain. Our contribution to the 
literature is two-fold. First, Traditional EKC literature focuses on the relationship between income level and environmental pollutions. This paper attempts to extend the EKC literature through exploring the effect of low-carbon innovations on $\mathrm{CO}_{2}$ emissions. Secondly, we further investigate possible heterogeneous impacts of different types of low-carbon innovations. With the development of directed technology change theory [3], theoretical literature gradually shed light on the heterogeneity within environmental innovation. That is, environmental technologies may differ in technological capacity, market size, or price, through the economic production function and pollution function, the environmental performance of technology innovation of a certain type may be different from other types. Unfortunately, few empirical studies have tested such a hypothesis. In this paper, we extend the literature on measurement of environmental innovation by subdividing low-carbon technology into two classes-namely clean technology and gray technology - examining their possible distinct impacts on $\mathrm{CO}_{2}$ emission and providing some evidence of heterogeneity within environmental technology.

Based on a data panel from 15 major inventor countries/economies during the period of 1992-2012, this paper firstly uses three patent-based innovation indicators to examine whether low-carbon innovation could significantly relate to $\mathrm{CO}_{2}$ reduction. Furthermore, we construct the clean innovation indicator by selecting patents with the potential for zero-carbon production or consumption from the overall low-carbon patents, and construct the gray innovation indicator by selecting the remaining low-carbon patents. We then examine whether clean innovation or gray innovation have a significant and negative effect on $\mathrm{CO}_{2}$ emission, for the purpose of investigating the possible heterogeneity between these two types of low-carbon innovation.

The empirical results indicate that low-carbon innovation does not have a significant impact on $\mathrm{CO}_{2}$ emissions. When illustrating this seemingly counterfactual result, we find that the heterogeneity within low-carbon technology matters. That is, according to the subsequent results, clean innovation significantly relates to $\mathrm{CO}_{2}$ reduction, while gray innovation does not have a clear impact. Therefore, when the two effects are added up, the overall impact of low-carbon innovation is not clear.

The rest of the paper is organized as follows. Section 2 briefly reviews the literature on the EKC empirics, and the literature on the effect of environmental innovation on $\mathrm{CO}_{2}$ emission. Section 3 presents the data, methodology, and variables. In Section 4, we show the results of the econometric analyses. In Section 5, conclusions are presented.

\section{Literature Review}

\subsection{Literature on Influential Factors of Environmental Performance (EP)}

Most related studies not only focus on $\mathrm{CO}_{2}$ emissions, but also on a broader concept of environmental performance (EP). For example, Lee \& Min [4] defined EP as carbon emissions, Ghisetti \& Quatraro [5] defined EP as the ratio between real value added and $\mathrm{CO}_{2}$ emissions, Picazo-Tadeo et al. [6] defined EP as an environmental productivity index based on Data Envelopment Analysis (DEA). Generally, there are at least three frameworks for investigating the influential factors of EP.

\section{(1) The Environmental Kuznets Curve Framework}

The empirical EKC literature focuses on testing the hypothesis of an inverted U-shaped curve between pollutions and economic development [7]. In classic EKC studies, economic growth is the only determinate of pollutant emissions. Such a reduced-form model encountered significant debate, since it may ignore some important influential factors of pollution emissions [8,9]. Following papers extended this literature by adding explanatory variables to the reduced-form EKC model. For example, in the context of open economy, Antweiler et al. [10] shed light on the impact of international trade on environment. Notably, a broad literature relies on decomposition introduced by Grossman \& Krueger [11] who took economic scale, economic structure, and technological progress as the main determinants of pollutant emissions [12]. Tsurumi \& Managi [13] tested the existence of 
the three effects by using a non-parametric econometric approach. In addition to the effects of scale, structure, and technology, Yin et al. focused on the impact of institutional factors [14].

(2) The IPAT or STIRPAT Framework

Long before the EKC literature, Ehrlich \& Holdren set out the IPAT framework [15]. The IPAT equation ( $(\mathrm{I}=\mathrm{PAT})$ indicates that population, affluence, and technology have impacts on pollution. Dietz \& Rosa [16] formulated a stochastic version of the IPAT equation with the name STIRPAT model. As commented by Carson [17], the original IPAT studies viewed population and affluence as primary driving forces of pollutions, which were challenged intensively in terms of both model specification and data quality. Nevertheless, following studies extended the STIRPAT model by accounting for other factors such as industrialization [18], age structure [19], urbanization [20], and environmental innovation [21].

(3) Production-Theoretical Decomposition (PDA) Framework

There is a large body of literature that uses decomposition analysis to attribute change of EP to several pre-defined effects. Here, we specially introduce the production-theoretical decomposition framework, since it enables us to investigate the role of technology change. The term PDA was first coined by Zhou \& Ang [22] which proposed a framework for decomposing $\mathrm{CO}_{2}$ emissions based on production theory. By applying frontier efficiency techniques, other studies in this line employ the PDA approach to investigate changes in total-factor carbon emission performance [23,24], energy productivity [25], and energy intensity [26]. Regarding the attribution of technology change to $\mathrm{EP}$, this literature is specialized in investigating the role played by catching up with best available environmental technologies and practices (BAT) [2]. Besides, studies of PDA framework typically take the technology change effect as given, without testing whether such effect exists and is significant. See Lin \& Du [26] for a review of different methodologies in this literature, such as structural decomposition analysis (SDA), index decomposition analysis (IDA), and production-theoretical decomposition (PDA).

\subsection{Literature on the Effect of Environmental Innovation on $\mathrm{CO}_{2}$ Emissions}

Most previous studies took it for granted that environmental innovation can necessarily improve environmental performance (e.g., $\mathrm{CO}_{2}$ reduction), whereas few empirical studies addressed the issue of the effectiveness of environmental innovation in achieving environmental goals [2].

With environmental research and development $(\mathrm{R} \& \mathrm{D})$ or patent data becoming accessible, there is an emerging literature investigating the impact of environmental innovation on $\mathrm{CO}_{2}$ emissions. Costantini et al. [27] focused on the comparison of effects of internal eco-innovation and interregional technology spillovers. Based on a panel data of Italian regions, they found that interregional technology spillovers were significantly related to EP (e.g., GHG emission intensity), while internal eco-innovation (measured by environmental patents) was not significant. Costantini et al. [2] further took domestic and foreign technology spillover as two different aspects of technology spillover. They carried out a cross-country and sectoral analysis, and found evidence for those indirect effects of eco-innovation on EP (e.g., $\mathrm{CO}_{2}$ emission intensity). Ghisetti \& Quatraro [5] focused on the vertical linkage amongst upstream sectors producing EIs and downstream sectors employing these technologies. They carried out an Italian cross-sectoral analysis and found such vertical linkage could introduce demand for EI and hence positively influence EP (e.g., value added $/ \mathrm{CO}_{2}$ emission). Using a sample of Japanese manufacturing firms from 2001 to 2010, Lee \& Min [4] found a significant and negative relationship between firm-level environmental R\&D investment and $\mathrm{CO}_{2}$ emissions.

Recently, some empirical studies further distinguished the impacts of different types of environmental technologies. For example, Lee \& Min [4] differentiated environmental R\&D and non-environmental R\&D. Wang et al. [28] carried out an empirical study using panel data of 30 Chinese provinces from 1997 to 2008, and found that impacts of fossil-fueled and carbon-free energy technology 
on $\mathrm{CO}_{2}$ emissions were different. Costantini et al. [2] subdivided EI into seven classes (e.g., renewable, transport, etc.) and examined their impacts on $\mathrm{CO}_{2}$ emission intensity, respectively. They found that each class of EI negatively affected $\mathrm{CO}_{2}$ intensity except for 'combustion technologies with mitigation potential'. In addition to heterogeneity, complementarity may also exist among innovation types. For example, it is necessary for manufacturers to integrate eco-innovations with product innovations or organization innovations. Gilli et al. [29] empirically tested if complementarity among innovation practices could improve EP (value added $/ \mathrm{CO}_{2}$ emission) but found such 'innovation complementarity' was not a main driving force of EP.

To sum up, while most empirical studies focused on EP which was measured by value added per $\mathrm{CO}_{2}$ emission or $\mathrm{CO}_{2}$ emission intensity, few studies shed light on the absolute level of $\mathrm{CO}_{2}$ emission. Furthermore, it is widely accepted that EI has a negative impact on those non-absolute-level measurements of EP, whereas Weina et al. [21] did not find any evidence of a significant role of green technology in $\mathrm{CO}_{2}$ reduction. Given the importance of both $\mathrm{CO}_{2}$ reduction and environmental innovation, it is worthwhile to further investigate the cause of the insignificant effect of EI. For this purpose, the EKC framework and the STIRPAT are available. Recent studies of EKC and STIRPAT share the same variables, since each literature develops by accounting for additional key determinants. Hence, there is no bright line between the two types of literature. Actually, some studies even tried to merge the EKC and STIRPAT models [14]. So this paper, which relies on the EKC framework, also takes account of influential factors appearing in the literature.

\section{Method and Data}

\subsection{Measurements and Decompositions of Low-Carbon Innovation}

There is no consensus on how to measure technology innovation (or technology progress from a macroeconomic perspective) in existing studies. Some researchers use energy intensity or time as a proxy for environmental technology progress [19,30]. Some studies use generic R\&D expenditure without specifying the technological domain, presuming that generic innovations would often result in greater efficiency of resource and hence less $\mathrm{CO}_{2}$ emissions per unit of output $[9,31]$. Such a hypothesis is intuitive but may ignore the heterogeneity within the broad technological domain. Thus, the resultant roles of innovation appear inconsistent when empirical tests are done based on different samples $[14,21,31]$.

We chose the patent-based innovation measurement because it is more available than other measurements and highly flexible in technology classification [2,32]. For the purpose of measuring innovation for specific environmental technology, there are at least three types of methodologies, including R\&D expenditure data, patent data, and scientific publication data [32]. Though patent counts data is an indirect and imperfect measurement of technological innovation, it is preferable for this study because it allows us to collect data in highly disaggregated forms by referring to patent classifications. That is, we can subdivide patents of low-carbon technology into patents of clean and gray technology as introduced below.

\subsubsection{Patent-Based Statistical Strategy of Low-Carbon Technology}

This study identifies and decomposes low-carbon technology according to the Y02 class from the Cooperative Patent Classification (CPC) system. In the 'European Patent Office (EPO) Worldwide Patent Statistical Database' (PATSTAT), all patents are tagged with CPC numbers. We classify patents of invention (PI) belonging to the Y02 class as low-carbon technologies. To keep track of technology development for climate change mitigation, United Nations Environment Program (UNEP), EPO, and International Centre for Trade and Sustainable Development (ICTSD) developed a new Y02 class in the CPC system [33,34]. The Y02 category provides the most accurate tagging of low-carbon patents available today and is becoming the international standard for low-carbon innovation studies [35]. In order to capture the whole inventive effort pursued by inventors, we chose to construct our 
indicators by counting patent applications instead of granted patents. We counted patent applications and assigned them to specific countries or economies according to the following strategies. (1) Using the concept of INPADOC patent family to identity same or similar patents (see Martinez [36] for concepts and differences of various types of patent family, especially the advantages of INPADOC family.). Double counting may exist in patent statistics when several patent applications protect one specific invention, especially when an inventor/applicant files patent applications in several patent offices to protect the same invention. For multiple patents belonging to the same INPADOC family, we only counted once and view all family members as a single invention; (2) Using fractional count to distribute an invention with inventors from different countries/economies. The country/region of residence of the inventor is used to indicate the origin of a patent. When the inventor information of a patent is missing, we simply use the country/region name of the patent office instead. The reason is called 'home bias', which means that the local inventors do not need to file a country/region information when they are applying in their home country/region [37]. When inventors of a patent are from different countries/economies, we calculated the ratio of the number of inventors from one economy to the total number of inventors, and took the ratio as the patent count of that economy; (3) Using 'EPO-equivalent coefficient' from Dechezleprêtre et al. [38] to deal with distinct patent breadths of different patent offices. Since the number of patents needed to protect an invention differs from one patent office to another (i.e., patent breadths are different), statistical bias may exist when computing or comparing counts of patent applied in different patent offices. To avoid this, we used the 'EPO-equivalent coefficient' provided by Dechezleprêtre et al. [38] as the weight of patent counts. See Appendix A for the value of 'EPO-equivalent coefficient'. As an example, the coefficient of Japan is 1.4, which means that seven patents filed at the Japan Patent Office result in approximately five patents filed at the European Patent Office.

\subsubsection{Identifying Clean and Gray Low-Carbon Technology}

The concept of low-carbon technology can be found in Dechezleprêtre \& Martin [39], Gillingham \& Sweeney [40], and Albino et al. [41]. Referring to existing patent classifications, we can identify the environmental technology according to either the IPC Green Inventory from World Intellectual Property Organization (WIPO) [42] or the OECD EnvTech category [43]. In terms of patent classifications, low-carbon technology belongs to environmental technology, so that the term 'environmental technology' can be viewed as a broad concept of low-carbon technology to some extent. In this paper, we used the narrow concept of low-carbon technology and identified it according to the CPC Y02 class from UNEP, EPO, and ICTSD [33].

Taking into account the heterogeneity within low-carbon technology, we divided the Y02 class into two subclasses: the first one is the clean low-carbon technology (clean technology, hereafter) which relates to zero-carbon production or consumption (e.g., Y02B10, integration of renewable energy sources in buildings); the second one is the gray low-carbon technology (gray technology, hereafter) which is not absolutely carbon-free, but with the potential of energy saving or climate change mitigation. The classification of clean technology and gray technology is listed in Appendix B.

\subsubsection{Indicators of Innovation}

In order to comprehensively understand the technology progress, this study constructs three patent-based indicators of innovation from different perspectives. The first is technology development indicator measured by simple patent counts [44]. This indicator provides a complete picture of inventive activity worldwide, because it accounts for the entire stock of patent priorities [45]. It can reflect how dynamic the inventive activity is [32,38]. The second is innovation quality indicator measured by counts of 'claimed patent priorities'. A 'claimed priority' refers to a patent priority that is claimed in at least two patent offices (i.e., with two patent family members). It excludes patent applications which have never been claimed, so it only accounts for high-value patents and thus reflects the innovation quality [45]. The third is the knowledge stock indicator calculated on the basis 
of the innovation quality indicator. While the first two are flow indicators, the last one is a stock indicator which captures the role played by knowledge as a stock variable in economic production function [46]. We constructed the knowledge stock variable as follows

$$
K_{i, t}=\sum_{s=0}^{\infty} e^{-\beta_{1} s}\left(1-e^{\beta_{2}(s+1)}\right) P A T_{i, s}
$$

where $K_{i, t}$ denotes the knowledge stock of low-carbon technology in economy $i$ at year $t$; PAT denotes the number of high-quality patents (i.e., claimed patent priorities); $s$ denotes the number of years before the current year; $\beta_{1}$ denotes the decay rate, $\beta_{2}$ denotes the diffusion rate. Referring to Popp [47], $\beta_{1}$ and $\beta_{2}$ are set to be 0.36 and 0.03 , respectively.

\subsection{Econometric Model}

By the EKC framework developed by Grossman [7], in the national level, the $\mathrm{CO}_{2}$ emission is driven by economic development through scale effect, structure effect, and technology effect. There are additional insights by other studies suggesting the importance of other factors like openness [12] and environmental policy $[14,21]$. We thus consider the following econometric model

$$
\ln C_{i t}=\alpha_{i}+\beta_{1} \ln L C I_{i t}+\beta_{2} \ln \text { structure }_{i t}+\beta_{3} \ln \text { scale }_{i t}+\beta_{j} Z_{j, i t}+\varepsilon_{i t}
$$

where $C_{i t}$ denotes $\mathrm{CO}_{2}$ emission for economy $i$ at year $t . \mathrm{LCI}_{i t}$, structure ${ }_{i t}$ and scale $e_{i t}$ denote low-carbon innovation, economic structure, and economic scale, respectively. $Z_{j, i t}$ denotes control variables, including openness [10,48], energy structure [14], generic technology progress [21], and environmental policy [49]. Given the log linearization of the model, the estimated coefficient represents the elasticity between the dependent variable and the independent variable, i.e., the size of the percentage change in the dependent variable with respect to one percentage change of the independent variable. Given the panel data analysis of Equation (2), we employ the fixed effects (FE) estimator and the random effects (RE) estimator, and adopt the Hausman test to determine the preferred one.

\subsection{Data and Variables}

This study is based on a data panel of 15 economies (see Appendix A for the list) from 1992 to 2012. The sample includes the top 15 inventor countries or economies in the world, accounting over 90 percent for the worldwide low-carbon patent applications during the research period. The time range of the dataset is limited, mainly due to the availability of patent application data. Specifically, in line with previous studies [45,50], we collected patent data starting from 1990, but found many missing values before 1992, and hence chose the study period from 1992 to 2012. Table 1 lists the specific descriptions of variables.

Table 1. Descriptions of variables.

\begin{tabular}{cl}
\hline \multicolumn{1}{c}{ Variables } & \multicolumn{1}{c}{ Description } \\
\hline C & $\begin{array}{l}\mathrm{CO}_{2} \text { emissions through consumption of oil, gas, and coal. } \\
\text { (Source: BP Statistical Review of World Energy [51]) }\end{array}$ \\
\hline LCI_development & $\begin{array}{l}\text { Technology development indicator for low-carbon innovation, counts of patents belonging } \\
\text { to Y02 class. } \\
\text { (Source: authors' calculation based on raw data from PATSTAT [52]) }\end{array}$ \\
\hline LCI_quality & $\begin{array}{l}\text { Innovation quality indicator for low-carbon innovation, counts of patents: (1) belonged to } \\
\text { Y02 class; (2) with at least two family members. } \\
\text { (Source: authors' calculation based on raw data from PATSTAT [52]) }\end{array}$ \\
\hline LCI_stock & $\begin{array}{l}\text { Knowledge stock indicator for low-carbon innovation, calculated by using method of Popp [47]. } \\
\text { (Source: authors' calculation based on raw data from PATSTAT [52]) }\end{array}$ \\
\hline
\end{tabular}


Table 1. Cont.

\begin{tabular}{cl}
\hline \multicolumn{1}{c}{ Variables } & \multicolumn{1}{c}{ Description } \\
\hline scale & $\begin{array}{l}\text { Economic scale, expenditure-side real GDP at chained PPPs (in mil. US\$2005). } \\
\text { (Source: PWT 9.0 [53]) }\end{array}$ \\
\hline structure & $\begin{array}{l}\text { Economic structure, ratio between capital stock at constant 2005 national prices } \\
\text { (in mil. US\$2005) and number of persons engaged (in millions). } \\
\text { (Source: PWT 9.0 [53]) }\end{array}$ \\
\hline openness & $\begin{array}{l}\text { Degree of openness, sum of import, and export/real GDP. } \\
\text { (Source: PWT 9.0 [53]) }\end{array}$ \\
\hline dirty energy rate & $\begin{array}{l}\text { Energy structure, the ratio between fossil energy consumptions and total } \\
\text { energy consumptions. } \\
\text { (Source: BP Statistical Review of World Energy [51]) }\end{array}$ \\
\hline RED_intensity & $\begin{array}{l}\text { R\&D expenditure per capita at constant prices and PPPs. } \\
\text { (Source: OECD statistics database [54]) }\end{array}$ \\
\hline Dummy_carbon price & $\begin{array}{l}\text { Dummy variable for carbon price policy, if economy } i \text { participates in a carbon market or } \\
\text { imposes carbon tax at year } t, \text { the dummy variable equals to 1, otherwise it equals to 0. }\end{array}$ \\
\hline
\end{tabular}

\section{Empirical Results}

\subsection{The Impact of Low-Carbon Innovation on $\mathrm{CO}_{2}$ Emissions}

Table 2 reports the estimation results of the baseline model, focusing on the impact of low-carbon innovation (LCI) on $\mathrm{CO}_{2}$ emissions. Column (1) shows the impact of LCI measured in terms of knowledge stock, while in Columns (2) and (3) LCI is measured in terms of innovation quality and technology development, respectively.

Through Columns (1)-(3), we do not find evidence of a significant influence of LCI on $\mathrm{CO}_{2}$ emissions. In each column, the estimated parameters of various LCI indicators are negative but insignificant. This result, in addition to existing literature on environmental performance, shows the role of LCI in low-carbon transition. Specially, LCI is capable of reducing $\mathrm{CO}_{2}$ intensity [2], but does not significantly relate to absolute $\mathrm{CO}_{2}$ reduction. As an explanation of such insignificant effect, we assume that the heterogeneity within the LCI matters. According to the construction process of LCI indicators, LCI involves clean technologies (e.g., clean energy production) and gray technologies (e.g., devices for improving energy efficiency). While clean innovation is helpful for $\mathrm{CO}_{2}$ reduction, the impact of gray innovation is not clear. For example, though energy efficiency can be improved by technology innovation, the substitution effect and income effect induced by efficiency gains could increase energy consumption, and hence offset the $\mathrm{CO}_{2}$ reduction effect of technology innovation. This phenomenon is called 'rebound effect' which makes the impact of gray innovation unclear $[40,55]$, and further affects the significance of LCI variables in our estimation. We will subsequently discuss this assumption in Section 4.2.

It is necessary to point out that the effects of LCI and generic technology progress (measured by $\ln R \mathcal{E} D \_$intensity) are different. The intensity of $R \& D$ expenditure captures the input level in the process of knowledge generation. From Columns (1)-(3), parameters of $\ln R \mathcal{E} D$ _intensity are significant and positive, which indicates that generic $\mathrm{R} \& \mathrm{D}$ expenditure does not necessarily cause $\mathrm{CO}_{2}$ reduction in the research period, which is in line with other studies [14,21]. The theory of directed technology change provides us with a suitable explanation [3]. That is that research activity and technology progress are not neutral, and they can be endogenously directed to either clean technology or dirty technology. When dirty technologies dominate, the increasing R\&D level will improve productivity of dirty industry and hence hinder $\mathrm{CO}_{2}$ reduction.

It is also worthwhile to consider other explanatory variables and control variables. (1) Economic scale has a significant and positive effect on $\mathrm{CO}_{2}$ emissions, indicated by the estimated parameter of Inscale; (2) Economic structure measured by capital deepening (i.e., lnstructure) positively affects $\mathrm{CO}_{2}$ 
emissions. A non-ignorable ratio of increasing capital worldwide is allocated to facilities, firms, or industries that are highly carbon intensive, which could stimulate $\mathrm{CO}_{2}$ emissions; (3) The dirty energy rate is positively related to $\mathrm{CO}_{2}$ emissions. The increasing consumption of fossil fuel makes it hard to delink economic growth from $\mathrm{CO}_{2}$ emissions; (4) The degree of openness (denoted by openness) negatively affects $\mathrm{CO}_{2}$ emissions. Higher degree of openness enables an economy to participate in low-carbon technological cooperation more intensively, such as joint research programs and technology transfer, etc., to move toward the global technological frontier, and hence to combat climate change.

Table 2. Estimation results (the impact of low-carbon innovation (LCI) on $\mathrm{CO}_{2}$ emissions).

\begin{tabular}{|c|c|c|c|}
\hline & (1) & (2) & (3) \\
\hline $\ln L C I \_s t o c k$ & $\begin{array}{l}-0.0133 \\
(0.0114)\end{array}$ & & \\
\hline $\ln L C I$ quality & & $\begin{array}{l}-0.0072 \\
(0.0096)\end{array}$ & \\
\hline $\ln L C I \_d e v e l o p m e n t$ & & & $\begin{array}{l}-0.0043 \\
(0.0105)\end{array}$ \\
\hline lnscale & $\begin{array}{c}0.1892 * * * \\
(0.0501)\end{array}$ & $\begin{array}{c}0.1839 * * * \\
(0.0500)\end{array}$ & $\begin{array}{c}0.1805 * * * \\
(0.0503)\end{array}$ \\
\hline lnstructure & $\begin{array}{l}0.2730^{* * *} \\
(0.0510)\end{array}$ & $\begin{array}{l}0.2607^{* * *} \\
(0.0491)\end{array}$ & $\begin{array}{c}0.2556^{* * *} \\
(0.0485)\end{array}$ \\
\hline $\ln R \mathcal{E} D$ _intensity & $\begin{array}{c}0.2218 * * * \\
(0.0352)\end{array}$ & $\begin{array}{c}0.2193 * * * \\
(0.0356)\end{array}$ & $\begin{array}{c}0.2158 \text { *** } \\
(0.0356)\end{array}$ \\
\hline dirty energy rate & $\begin{array}{c}2.9021 * * * \\
(0.1733)\end{array}$ & $\begin{array}{c}2.9280 * * * \\
(0.1711)\end{array}$ & $\begin{array}{c}2.9353 * * * \\
(0.1722)\end{array}$ \\
\hline openness & $\begin{array}{c}-0.0857^{* *} \\
(0.0386)\end{array}$ & $\begin{array}{c}-0.0931 \text { ** } \\
(0.0379)\end{array}$ & $\begin{array}{c}-0.0928^{* *} \\
(0.0382)\end{array}$ \\
\hline Dummy_carbon price & $\begin{array}{c}-0.0586^{* * *} \\
(0.0132)\end{array}$ & $\begin{array}{c}-0.0603^{* * *} \\
(0.0133)\end{array}$ & $\begin{array}{c}-0.0622 \text { *** } \\
(0.0130)\end{array}$ \\
\hline cons & $\begin{array}{c}-3.8124^{* * *} \\
(0.7508)\end{array}$ & $\begin{array}{c}-3.5925^{* * *} \\
(0.7121)\end{array}$ & $\begin{array}{c}-3.4768^{* * * *} \\
(0.6976)\end{array}$ \\
\hline $\mathrm{R}^{2}$ & 0.8387 & 0.8382 & 0.8380 \\
\hline F statistic & $215.34^{* * *}$ & $214.65^{* * *}$ & $214.29 * * *$ \\
\hline Hausman test & $185.28^{* * *}$ & $184.42^{* * *}$ & $181.10^{* * *}$ \\
\hline method & $\mathrm{FE}$ & $\mathrm{FE}$ & $\mathrm{FE}$ \\
\hline$N$ & 312 & 312 & 312 \\
\hline
\end{tabular}

Standard errors in parentheses. ${ }^{*} p<0.10 ;{ }^{* *} p<0.05 ;{ }^{* * *} p<0.01$. The number of observations is 312 due to missing values of $\ln R \mathcal{E} D_{-}$intensity. For simplicity, results of RE are not reported, since the FE model is chosen through the Hausman test in each case.

\subsection{Impacts of Clean and Gray Innovation on $\mathrm{CO}_{2}$ Emissions}

To investigate the heterogeneity within low-carbon innovations, we divide low-carbon technology into two subgroups, namely clean and gray low-carbon technology. Table 2 reports the estimation results: Columns (1), (3), and (5) focus on the impact of clean innovation, while Columns (2), (4), and (6) focus on the impact of gray innovation. Specifically, Table 3 compares the impacts of clean and gray innovation measured by various proxy indicators: Columns (1) and (2) are about the knowledge stock indicator; Columns (3) and (4) are about the innovation quality indicator; Columns (5) and (6) are about the technology development indicator. 
Table 3. Estimation results (impacts of clean or gray innovation on $\mathrm{CO}_{2}$ emissions).

\begin{tabular}{|c|c|c|c|c|c|c|}
\hline & (1) & (2) & (3) & (4) & (5) & (6) \\
\hline lncleanLCI_stock & $\begin{array}{c}-0.0186^{*} \\
(0.0098)\end{array}$ & & & & & \\
\hline lngrayLCI_stock & & $\begin{array}{l}-0.0050 \\
(0.0123)\end{array}$ & & & & \\
\hline IncleanLCI_quality & & & $\begin{array}{c}-0.0150 * * \\
(0.0069)\end{array}$ & & & \\
\hline lngrayLCI_quality & & & & $\begin{array}{c}0.0115 \\
(0.0109)\end{array}$ & & \\
\hline IncleanLCI_development & & & & & $\begin{array}{l}-0.0078 \\
(0.0079)\end{array}$ & \\
\hline IngrayLCI_development & & & & & & $\begin{array}{l}0.0307^{* *} \\
(0.0155)\end{array}$ \\
\hline lnstructure & $\begin{array}{c}0.2817^{* * *} \\
(0.0501)\end{array}$ & $\begin{array}{c}0.2611^{* * *} \\
(0.0525)\end{array}$ & $\begin{array}{c}0.2712^{* * *} \\
(0.0479)\end{array}$ & $\begin{array}{c}0.2334 * * * \\
(0.0500)\end{array}$ & $\begin{array}{c}0.2580^{* * *} \\
(0.0482)\end{array}$ & $\begin{array}{c}0.0041 \\
(0.0570)\end{array}$ \\
\hline lnscale & $\begin{array}{c}0.1907^{* * *} \\
(0.0492)\end{array}$ & $\begin{array}{c}0.1803^{* * *} \\
(0.0503)\end{array}$ & $\begin{array}{c}0.1913^{* * *} \\
(0.0494)\end{array}$ & $\begin{array}{c}0.1670^{* * *} \\
(0.0500)\end{array}$ & $\begin{array}{c}0.1853^{* * *} \\
(0.0497)\end{array}$ & $\begin{array}{c}0.6306^{* * *} \\
(0.0410)\end{array}$ \\
\hline openness & $\begin{array}{c}-0.0758^{*} \\
(0.0389)\end{array}$ & $\begin{array}{c}-0.0929^{* *} \\
(0.0382)\end{array}$ & $\begin{array}{c}-0.0903^{* *} \\
(0.0377)\end{array}$ & $\begin{array}{c}-0.0942 * * \\
(0.0377)\end{array}$ & $\begin{array}{c}-0.0878^{* *} \\
(0.0385)\end{array}$ & $\begin{array}{c}-0.3066^{* * *} \\
(0.0434)\end{array}$ \\
\hline dirty energy rate & $\begin{array}{c}2.8538^{* * *} \\
(0.1753)\end{array}$ & $\begin{array}{c}2.9476^{* * *} \\
(0.1689)\end{array}$ & $\begin{array}{c}2.8795^{* * *} \\
(0.1698)\end{array}$ & $\begin{array}{c}2.9330 * * * \\
(0.1684)\end{array}$ & $\begin{array}{c}2.9151 * * * \\
(0.1721)\end{array}$ & $\begin{array}{c}3.0661^{* * *} \\
(0.1975)\end{array}$ \\
\hline $\ln R \mathcal{E} D \_$intensity & $\begin{array}{c}0.2350 * * * \\
(0.0361)\end{array}$ & $\begin{array}{c}0.2141^{* * *} \\
(0.0347)\end{array}$ & $\begin{array}{c}0.2397^{* * *} \\
(0.0352)\end{array}$ & $\begin{array}{c}0.2003^{* * *} \\
(0.0350)\end{array}$ & $\begin{array}{c}0.2202^{* * *} \\
(0.0352)\end{array}$ & $\begin{array}{l}0.0751^{*} \\
(0.0416)\end{array}$ \\
\hline Dummy_carbon price & $\begin{array}{c}-0.0543^{* * *} \\
(0.0134)\end{array}$ & $\begin{array}{c}-0.0622^{* * *} \\
(0.0130)\end{array}$ & $\begin{array}{c}-0.0544^{* * *} \\
(0.0131)\end{array}$ & $\begin{array}{c}-0.0676^{* * *} \\
(0.0130)\end{array}$ & $\begin{array}{c}-0.0599 * * * \\
(0.0131)\end{array}$ & $\begin{array}{c}-0.0984^{* * *} \\
(0.0163)\end{array}$ \\
\hline cons & $\begin{array}{c}-3.9896^{* * *} \\
(0.7236)\end{array}$ & $\begin{array}{c}-3.5533^{* * *} \\
(0.7873)\end{array}$ & $\begin{array}{c}-3.9103^{* * *} \\
(0.6850)\end{array}$ & $\begin{array}{c}-2.9788^{* * *} \\
(0.7425)\end{array}$ & $\begin{array}{c}-3.5743^{* * *} \\
(0.6803)\end{array}$ & $\begin{array}{c}-5.9367^{* * *} \\
(0.7859)\end{array}$ \\
\hline$R^{2}$ & 0.8399 & 0.8380 & 0.8327 & 0.8370 & 0.8384 & 0.8383 \\
\hline F statistic & $217.32 * * *$ & $214.29 * * *$ & $204.00^{* * *}$ & $212.04^{* * *}$ & $215.01 * * *$ & $214.84^{* * *}$ \\
\hline Hausman test & $186.00^{* * *}$ & $182.22 * * *$ & $195.08^{* * *}$ & $178.11^{* * *}$ & $181.69^{* * *}$ & $177.81^{* * *}$ \\
\hline method & FE & FE & $\mathrm{FE}$ & FE & FE & FE \\
\hline$N$ & 312 & 312 & 312 & 312 & 312 & 312 \\
\hline
\end{tabular}

Standard errors in parentheses. ${ }^{*} p<0.10 ;{ }^{* *} p<0.05 ;{ }^{* * *} p<0.01$. The number of observations is 312 due to missing values of $\ln R \mathcal{E} D$ _intensity. For simplicity, results of RE are not reported, since the FE model is chosen through the Hausman test in each case.

Generally speaking, for each pair of comparison such as Columns (1) and (2), the estimated parameters of clean and gray innovation are different in sign and (or) significance. We thus find evidence of distinct impacts of clean and gray innovation on $\mathrm{CO}_{2}$ emissions, which was given as a hypothesis in Section 4.1 .

The impact of clean innovation is significant and negative when the innovation indicator is based on counts of high-quality patents. Measured by the knowledge stock variable and innovation quality variable in Columns (1) and (3) respectively, clean innovation shows a significant and negative effect on $\mathrm{CO}_{2}$ emissions. Clean innovation creates new methods that make production or consumption carbon-free. Moreover, in the theory of directed technology change, new clean technology competes against traditional dirty technology which induces carbon emissions; and if the technological capacity of clean technology is high enough, firms would have an incentive to shift their production toward less carbon-intensive products $[3,56]$. As a result, the higher level of clean innovation leads to the rise of less carbon-intensive industry, and drives the economy toward a clean transition. In Column (5), the estimated parameter of clean innovation is negative but not significant, when innovation indicator is based on counts of patents without quality filtering. We explain this insignificant effect as follows. Though the technology development indicator in Column (5) can reflect how dynamic 
the clean inventive activity is, it contains massive information of low-quality patents which cannot represent the marginal change of technological capacity. Moreover, since many patents have very low value, the patent number without quality filtering does not perfectly reflect the value of technological innovation [38]. Thus, when clean technology development is driven mostly by low-quality patents, it may not behave as expected in climate change mitigation. For that reason, the patent number without quality filtering is not the first option when measuring environmental innovation [32]. This result also reminds us of careful use of various patent-based indicators. Specifically, high-quality patent numbers are more suitable for assessing the value or impact of environmental innovation, while patent numbers without quality filtering generally enable us to keep track of the intensity of inventive activity that does not necessarily cause valuable outcomes of innovation.

In Columns (2), (4), and (6), the estimated parameters of gray innovation are different in sign and (or) significance, which indicates that the impact of gray innovation on $\mathrm{CO}_{2}$ emissions is not clear. We explain this result from the perspective of energy efficiency innovation which is a crucial part of gray innovation. Although energy efficiency innovation represents our pursuit of more efficient energy use, it also has side effects which can trigger energy consumption [55]. This result is in line with a broad literature of rebound effect, where many empirical studies do not find consistent results regarding the effect of energy efficiency improvement on energy consumption or carbon emissions [57]. Taking combustion efficiency technology as an example, through the fuel injection device (CPC number: Y02T10/123), we can improve the fuel efficiency of vehicles, but this may in turn stimulate driving demands of drivers, and increase fossil fuel consumption and $\mathrm{CO}_{2}$ emissions.

\section{Conclusions}

This study aimed at investigate the impact of low-carbon technology innovation (LCI) on $\mathrm{CO}_{2}$ emissions, with a special focus on the heterogeneity within LCI. By using a dataset that covers 15 major economies from 1992 to 2012, the empirical results based on an EKC framework showed that the $\mathrm{LCI}$ is not a significantly influential factor of $\mathrm{CO}_{2}$ emissions. To explain the insignificant effect of LCI, we further divided low-carbon technology into two subgroups and test their individual impacts. The results show that: (1) the clean low-carbon innovation has a significantly negative effect on $\mathrm{CO}_{2}$ emissions; (2) the effect of gray low-carbon innovation is not clear. By adding up these two heterogeneous impacts, we can explain the insignificance of the total LCI.

This study finds new evidence of heterogeneous impacts of $\mathrm{LCI}$ on $\mathrm{CO}_{2}$ emissions. The heterogeneity within environmental technology is a basic hypothesis in the theory of directed technology change (DTC). However, this study is theoretically insufficient to fully understand the potential of LCI to prevent climate disaster. Within the DTC framework, the elasticity of substitution among environmental technologies represents a parameter on which the transitional dynamics and environmental performance of environmental innovation crucially depends. Though this paper does not move forward in this direction, the technological innovation data enables future studies to empirically evaluate the elasticity of substitution between clean innovation and the others. Besides, this study is related with a huge literature of Porter Hypothesis which indicates that strict environmental regulation triggers the discovery of cleaner technologies [3]. Since certain types of low-carbon technologies have significant environmental performance in our results, it still worth conducting further investigation into the mediation role of LCI in the casual relationship between environmental regulation and environmental performance.

Furthermore, in this study, impacts of R\&D expenditure, low-carbon innovation, clean innovation, and gray innovation on $\mathrm{CO}_{2}$ emissions are different, which should attract attention of policy makers. That is, although gray innovation or more general low-carbon innovation can reduce $\mathrm{CO}_{2}$ intensity as shown in other studies $[5,21]$, they do not necessarily cause absolute $\mathrm{CO}_{2}$ reduction. With a vision of a zero-carbon future, policy makers in the world should encourage clean low-carbon innovation more intensively, such as clean energy production technology and clean vehicle technology. 
Acknowledgments: This paper is supported by: National Natural Science Foundation of China (No. 71603148); Shaanxi Provincial Social Science Foundation, China (No. 2016D036); Shandong Provincial Natural Science Foundation, China (No. ZR2016GB10); China Postdoctoral Science Foundation (No. 2016M590627); the Fundamental Research Funds of Shandong University. We thank the four anonymous reviewers for their helpful comments and suggestions which led to an improved version of this paper.

Author Contributions: Zheming Yan, Lan Yi, Kerui Du, and Zhiming Yang conceived, designed, prepared, and revised the paper together. All authors read and approved the final manuscript.

Conflicts of Interest: The authors declare no conflict of interest.

\section{Appendix A}

Table A1. 'EPO-equivalent coefficient' for main patent offices.

\begin{tabular}{cccc}
\hline $\begin{array}{c}\text { Patent Office } \\
\text { (ISO Code) }\end{array}$ & $\begin{array}{c}\text { Patent Breadth } \\
\text { Coefficient }\end{array}$ & $\begin{array}{c}\text { Patent Office } \\
\text { (ISO Code) }\end{array}$ & $\begin{array}{c}\text { Patent Breadth } \\
\text { Coefficient }\end{array}$ \\
\hline JPN & 0.72 & GBR & 0.94 \\
TWN & 0.74 & USA & 0.97 \\
AUS & 0.80 & SWZ & 0.98 \\
KOR & 0.82 & AUT & 0.99 \\
RUS & 0.90 & FRA & 0.99 \\
CHN & 0.91 & EPO & 1 \\
INA & 0.93 & BEL & 1.02 \\
MEX & 0.93 & ITA & 1.08 \\
CAN & 0.94 & LUX & 1.14 \\
DNK & 0.94 & DEU & 1.15 \\
\hline
\end{tabular}

Source: Dechezleprêtre et al. [38]; Note: The sample economies are AUT, CAN, CHN, DEU, DNK, ESP, FRA, GBR, ITA, JPN, NLD, KOR, SWE, TWN, and USA. For sample economies which do not appear in Table A1, we set their coefficient to 1 .

\section{Appendix B}

To subdivide low-carbon technology into clean technology and gray technology, we check the Y02 class in Cooperative Patent Classification and identify each subclass based on concepts of clean and gray low-carbon technology from existing literature [58,59]. In this study, the whole Y02 class represents low-carbon technology, patents with CPC numbers in Table A2 belong to the clean technology, and the rest of Y02 patents belong to gray technology.

Table A2. The CPC number of clean low-carbon technology.

\begin{tabular}{ccl}
\hline $\begin{array}{c}\text { Technological } \\
\text { Domains }\end{array}$ & \multicolumn{1}{c}{ CPC Classes } & \multicolumn{1}{c}{ Descriptions } \\
\hline \multirow{2}{*}{ Building } & Y02B10 & Integration of renewable energy sources in buildings \\
\cline { 2 - 3 } $\begin{array}{c}\text { Dealing with } \\
\text { greenhouse gases }\end{array}$ & Y02B90/1 & Applications of fuel cells in buildings \\
\hline & Y02E10 & $\mathrm{CO}_{2}$ capture or storage \\
\cline { 2 - 3 } & Y02E30 & Energy generation through renewable energy sources \\
\cline { 2 - 3 } Energy & Y02E50 & Technologies for the production of fuel of non-fossil origin \\
\cline { 2 - 3 } & Y02E60/3 & Hydrogen technology \\
\cline { 2 - 3 } & Y02E60/5 & Fuel cells \\
\cline { 2 - 3 } & Y02E70/1 & Hydrogen from electrolysis with energy of non-fossil origin \\
\cline { 2 - 3 } & Y02E70/2 & Systems combining fuel cells with production of fuel of non-fossil origin \\
\hline & Y02E70/3 & $\begin{array}{l}\text { Systems combining energy storage with energy generation of } \\
\text { non-fossil origin }\end{array}$ \\
\hline
\end{tabular}


Table A2. Cont.

\begin{tabular}{|c|c|c|}
\hline $\begin{array}{l}\text { Technological } \\
\text { Domains }\end{array}$ & CPC Classes & Descriptions \\
\hline \multirow{12}{*}{ Transportation } & Y02T10/38 & Use of non-fossil fuels in internal combustion engine based vehicles \\
\hline & Y02T10/64 & Electric machine technologies for applications in electromobility \\
\hline & Y02T10/70 & Energy storage for electromobility \\
\hline & Y02T10/72 & Electric energy management in electromobility \\
\hline & Y02T10/80 & $\begin{array}{l}\text { Technologies aiming to reduce greenhouse gas emissions common to all } \\
\text { road transportation technologies }\end{array}$ \\
\hline & Y02T10/90 & $\begin{array}{l}\text { Energy harvesting concepts as power supply for auxiliaries' energy } \\
\text { consumption e.g., photovoltaic sun-roof }\end{array}$ \\
\hline & Y02T50/74 & Enabling use of bio fuels in aeronautics or air transport \\
\hline & Y02T50/90 & Eco-design in aeronautics or air transport \\
\hline & $\begin{array}{c}\text { Y02T70/5218, 5227, } \\
5236,5245,5254,58,59\end{array}$ & $\begin{array}{l}\text { Measures to reduce greenhouse gas emissions related to the propulsion } \\
\text { system of maritime or waterway transport }\end{array}$ \\
\hline & Y02T90/1 & Technologies related to electric vehicle charging \\
\hline & Y02T90/3 & Application of fuel cell technology to transportation \\
\hline & Y02T90/4 & Application of hydrogen technology to transportation \\
\hline
\end{tabular}

\section{References}

1. IEA. Energy Technology Perspectives. 2016. Available online: http://www.oecd-ilibrary.org/energy/ (accessed on 1 February 2017).

2. Costantini, V.; Crespi, F.; Marin, G.; Paglialunga, E. Eco-innovation, sustainable supply chains and environmental performance in European industries. J. Clean. Prod. 2016, in press.

3. Acemoglu, D.; Aghion, P.; Bursztyn, L.; Hemous, D. The environment and directed technical change. Am. Econ. Rev. 2012, 102, 131-166. [CrossRef] [PubMed]

4. Lee, K.; Min, B. Green R\&D for eco-innovation and its impact on carbon emissions and firm performance. J. Clean. Prod. 2015, 108, 534-542.

5. Ghisetti, C.; Quatraro, F. Green Technologies and Environmental Productivity: A Cross-sectoral Analysis of Direct and Indirect Effects in Italian Regions. Ecol. Econ. 2017, 132, 1-13. [CrossRef]

6. Picazo-Tadeo, A.J.; Castillo-Giménez, J.; Beltrán-Esteve, M. An intertemporal approach to measuring environmental performance with directional distance functions: Greenhouse gas emissions in the European Union. Ecol. Econ. 2014, 100, 173-182. [CrossRef]

7. Grossman, G.M. Pollution and growth: What do we know? In The Economics of Sustainable Development; Goldin, I., Winters, L.A., Eds.; Cambridge University Press: Cambridge, UK, 1995; pp. 19-46.

8. Stern, D.I. The rise and fall of the environmental kuznets curve. World Dev. 2004, 32, 1419-1439. [CrossRef]

9. Cole, M.A.; Elliott, R.J.R.; Shimamoto, K. Industrial characteristics, environmental regulations and air pollution: an analysis of the UK manufacturing sector. J. Environ. Econ. Manag. 2005, 50, 121-143. [CrossRef]

10. Antweiler, W.; Copeland, B.R.; Taylor, M.S. Is free trade good for the environment? Am. Econ. Rev. 2001, 91, 877-908. [CrossRef]

11. Grossman, G.M.; Krueger, A.B. Environmental impacts of a North American Free Trade Agreement. In The US-Mexico Free Trade Agreement; Garber, P., Ed.; MIT Press: Cambridge, MA, USA, 1993.

12. Brock, W.A.; Taylor, M.S. Economic growth and the environment: A review of theory and empirics. In Handbook of Economic Growth, 1st ed.; Durlauf, S., Aghion, P., Eds.; Elsevier: Amsterdam, The Netherlands, 2006; pp. 1749-1821.

13. Tsurumi, T.; Managi, S. Decomposition of the environmental kuznets curve: Scale, technique, and composition Effects. Environ. Econ. Policy Stud. 2010, 11, 19-36. [CrossRef]

14. Yin, J.; Zheng, M.; Chen, J. The effects of environmental regulation and technical progress on $\mathrm{CO}_{2} \mathrm{Kuznets}$ curve: An evidence from China. Energy Policy 2015, 77, 97-108. [CrossRef]

15. Ehrlich, P.R.; Holdren, J.P. Impact of population growth. Science 1971, 171, 1212-1217. [CrossRef] [PubMed] 
16. Dietz, T.; Rosa, E.A. Effects of population and affluence on $\mathrm{CO}_{2}$ emissions. Proc. Natl. Acad. Sci. USA 1997, 94, 175-179. [CrossRef] [PubMed]

17. Carson, R.T. The environmental Kuznets curve: Seeking empirical regularity and theoretical structure. Rev. Environ. Econ. Policy 2010, 4, 3-23. [CrossRef]

18. York, R.; Rosa, E.A.; Dietz, T. STIRPAT, IPAT and ImPACT: Analytic tools for unpacking the driving forces of environmental impacts. Ecol. Econ. 2003, 46, 351-365. [CrossRef]

19. Fan, Y.; Liu, L.; Wu, G.; Wei, Y. Analyzing impact factors of $\mathrm{CO}_{2}$ emissions using the STIRPAT model. Environ. Impact Assess. Rev. 2006, 26, 377-395. [CrossRef]

20. Martínez-Zarzoso, I.; Maruotti, A. The impact of urbanization on $\mathrm{CO}_{2}$ emissions: Evidence from developing countries. Ecol. Econ. 2011, 70, 1344-1353. [CrossRef]

21. Weina, D.; Gilli, M.; Mazzanti, M.; Nicolli, F. Green inventions and greenhouse gas emission dynamics: A close examination of provincial Italian data. Environ. Econ. Policy Stud. 2016, 18, 247-263. [CrossRef]

22. Zhou, P.; Ang, B.W. Decomposition of aggregate $\mathrm{CO}_{2}$ emissions: A production-theoretical approach. Energy Econ. 2008, 30, 1054-1067. [CrossRef]

23. Zhou, P.; Ang, B.W.; Han, J.Y. Total factor carbon emission performance: A Malmquist index analysis. Energy Econ. 2010, 32, 194-201. [CrossRef]

24. Zhang, N.; Wang, B.; Liu, Z. Carbon emissions dynamics, efficiency gains, and technological innovation in China's industrial sectors. Energy 2016, 99, 10-19. [CrossRef]

25. Wang, H.; Zhou, P.; Zhou, D.Q. Scenario-based energy efficiency and productivity in China: A non-radial directional distance function analysis. Energy Econ. 2013, 40, 795-803. [CrossRef]

26. Lin, B.; Du, K. Decomposing energy intensity change: A combination of index decomposition analysis and production-theoretical decomposition analysis. Appl. Energy 2014, 129, 158-165. [CrossRef]

27. Costantini, V.; Mazzanti, M.; Montini, A. Environmental performance, innovation and spillovers: Evidence from a regional NAMEA. Ecol. Econ. 2013, 89, 101-114. [CrossRef]

28. Wang, Z.; Yang, Z.; Zhang, Y.; Yin, J. Energy technology patents- $\mathrm{CO}_{2}$ emissions nexus: An empirical analysis from China. Energy Policy 2012, 42, 248-260. [CrossRef]

29. Gilli, M.; Mancinelli, S.; Mazzanti, M. Innovation complementarity and environmental productivity effects: Reality or delusion? Evidence from the EU. Ecol. Econ. 2014, 103, 56-67. [CrossRef]

30. Du, L.; Wei, C.; Cai, S. Economic development and carbon dioxide emissions in China: Provincial panel data analysis. China Econ. Rev. 2012, 23, 371-384. [CrossRef]

31. Cole, M.A.; Elliott, R.J.R.; Okubo, T.; Zhou, Y. The carbon dioxide emissions of firms: A spatial analysis. J. Environ. Econ. Manag. 2013, 65, 290-309. [CrossRef]

32. Popp, D. The Role of Technological Change in Green Growth. NBER Working Paper No. 18506. 2012. Available online: http:/ / www.nber.org (accessed on 1 February 2016).

33. UNEP; EPO; ICTSD. Patent and Clean Energy: Bridging the Gap between Evidence and Policy. 2009. Available online: http:/ /www.epo.org/clean-energy (accessed on 1 February 2016).

34. Veefkind, V.; Hurtado-Albir, J.; Angelucci, S.; Karachalios, K.; Thumm, N. A new EPO classification scheme for climate change mitigation technologies. World Pat. Inf. 2012, 34, 106-111. [CrossRef]

35. Calel, R.; Dechezleprêtre, A. Environmental policy and directed technological change: Evidence from the European carbon market. Rev. Econ. Stat. 2016, 98, 173-191. [CrossRef]

36. Martinez, C. Insight into Different Types of Patent Families. OECD Science, Technology and Industry Working Papers 2010/02. 2010. Available online: http://www.oecd-ilibrary.org/ (accessed on 1 February 2016).

37. De Rassenfosse, G.; Dernis, H.; Guellec, D.; Picci, L.; van Pottelsberghe De La Potterie, B. The worldwide count of priority patents: A new indicator of inventive activity. Res. Policy 2013, 42, 720-737. [CrossRef]

38. Dechezleprêtre, A.; Glachant, M.; Hascic, I.; Johnstone, N.; Meniere, Y. Invention and transfer of climate change-Mitigation technologies: A global analysis. Rev. Environ. Econ. Policy 2011, 5, 109-130. [CrossRef]

39. Dechezleprêtre, A.; Martin, R. Low carbon innovation in the UK: Evidence from patent data. Centre for Climate Change Economics and Policy (CCCEP) and Grantham Research Institute on Climate Change Policy Paper. 2010. Available online: http://www.lse.ac.uk/GranthamInstitute/publication/ (accessed on 1 February 2016).

40. Gillingham, K.; Sweeney, J. Barriers to implementing low-carbon technologies. Clim. Chang. Econ. 2012, 3, 1250019. [CrossRef] 
41. Albino, V.; Ardito, L.; Dangelico, R.M.; Messeni Petruzzelli, A. Understanding the development trends of low-carbon energy technologies: A patent analysis. Appl. Energy 2014, 135, 836-854. [CrossRef]

42. WIPO. IPC Green Inventory. 2012. Available online: http://www.wipo.int/classifications/ipc/en/est (accessed on 1 February 2016).

43. OECD. Invention and Transfer of Environmental Technologies. 2011. Available online: http://www.oecdilibrary.org/environment/ (accessed on 1 February 2016).

44. Haščič, I.; Migotto, M. Measuring Environmental Innovation Using Patent Data. OECD Environment Working Papers No. 89. 2015. Available online: http://www.oecd-ilibrary.org/content/workingpaper/ 5js009kf48xw-en (accessed on 1 February 2016).

45. Haščič, I.; Silva, J.; Johnstone, N. The Use of Patent Statistics for International Comparisons and Analysis of Narrow Technological Fields. OECD Science, Technology and Industry Working Papers 2015/05. 2015. Available online: http:/ /dx.doi.org/10.1787/5js03z98mvr7-en (accessed on 1 February 2016).

46. Verdolini, E.; Galeotti, M. At home and abroad: An empirical analysis of innovation and diffusion in energy technologies. J. Environ. Econ. Manag. 2011, 61, 119-134. [CrossRef]

47. Popp, D.C. The effect of new technology on energy consumption. Resour. Energy Econ. 2001, 23, $215-239$. [CrossRef]

48. Zhou, X.; Zhang, J.; Li, J. Industrial structural transformation and carbon dioxide emissions in China. Energy Policy 2013, 57, 43-51. [CrossRef]

49. Carrión-Flores, C.E.; Innes, R. Environmental innovation and environmental performance. J. Environ. Econ. Manag. 2010, 59, 27-42. [CrossRef]

50. Conway, D.; Dechezleprêtre, A.; Haščič, I.; Johnstone, N. Invention and diffusion of water supply and water efficiency technologies: Insights from a global patent dataset. Water Econ. Policy 2015, 01, 1550010. [CrossRef]

51. BP. BP Statistical Review of World Energy; BP P.L.C: London, UK, 2014.

52. EPO. EPO Worldwide Patent Statistical (PATSTAT) Database; 2014 Autumn Edition; European Patent Office: Munich, Germany, 2014.

53. Feenstra, R.C.; Inklaar, R.; Timmer, M.P. The next generation of the Penn World Table. J. R. Soc. Interface 2015, 7, 1025-1031. [CrossRef]

54. OECD. OECD Statistics Database. Available online: http:/ / stats.oecd.org/ (accessed on 1 February 2016).

55. Saunders, H.D. Historical evidence for energy efficiency rebound in 30 US sectors and a toolkit for rebound analysts. Technol. Forecast. Soc. Chang. 2013, 80, 1317-1330. [CrossRef]

56. Acemoglu, D.; Akcigit, U.; Hanley, D.; Kerr, W. Transition to clean technology. J. Political Econ. 2016, 124, 52-104. [CrossRef]

57. Herring, H.; Sorrell, S. Energy Efficiency and Sustainable Consumption: The Rebound Effect; Palgrave Macmillan: Hampshire, UK, 2009; pp. 85-98.

58. Dechezleprêtre, A.; Martin, R.; Mohnen, M. Knowledge Spillovers from Clean and Dirty Technologies: A Patent Citation Analysis. Centre for Climate Change Economics and Policy Working Paper No. 151. 2013. Available online: http:/ /www.lse.ac.uk/GranthamInstitute/publication/ (accessed on 1 February 2016).

59. Aghion, P.; Dechezleprêtre, A.; Hemous, D.; Martin, R.; Van Reenen, J. Carbon taxes, path dependency and directed technical change: Evidence from the auto industry. J. Political Econ. 2016, 124, 1-51. [CrossRef]

(C) 2017 by the authors. Licensee MDPI, Basel, Switzerland. This article is an open access article distributed under the terms and conditions of the Creative Commons Attribution (CC BY) license (http:/ / creativecommons.org/licenses/by/4.0/). 